IIUC STUDIES

ISSN 1813-7733

Vol.- 9, December 2012

(p 261-278)

\title{
English Literature from the “Other” Perspective: A Thought and an Approach
}

\author{
Umme Salma*
}

\begin{abstract}
English Literature as the knowledge of the former master is an exclusively challenging discipline to be focused from "the Other" perspective, from Muslim perspective, one among many Others. It is a bellicose field because in the postcolonial world its presence reminds of the colonial past, and declares the continuance of the myriad ideological projections and paradigmatic speculations of that past in the neocolonial form. Still postcolonial Indian Muslim societies are promoting and propagating English knowledge in every stage of educational institutions, and thus creating a culturally hybrid/syncretic nation which can neither accept Englishness entirely nor reject its own cultural inheritance and realities totally. Whereas other postcolonial nations can approve, accept and accelerate the mixed-up jumbled cultural syncretism gradually losing or conforming their native cultural signifiers with Western culture, Muslims cannot because the ideology and approach to life of Islam are straightly opposite to the English knowledge, emanated from the Judeo-Christian and Greco-Latin cultural heritage. Keeping in view the aforementioned ideas, the paper argues that this is high time to review this epistemological crisis from historical set up and to read English literature from the "Other" point of view. Therefore, it proposes some ways to re-read the English canonical compositions and puts forward as specimen the re-reading/teaching method of ENG: 2420, titled "English Poetry: 17th \&18th Centuries" from the undergraduate syllabus of IIUC.
\end{abstract}

Key words: English literature, Muslim, the "Other", hybridity/syncretism, cultural identity.

\footnotetext{
${ }^{*}$ Lecturer, Department of English Language and Literature, IIUC
} 


\section{Introduction:}

English Literature as the knowledge of the former master is an exclusively challenging discipline to be focused from "the Other" perspective, from Muslim perspective, one among many Others. It is a bellicose field because in the postcolonial world its presence reminds of the colonial past, and declares the continuance of the myriad ideological projections and paradigmatic speculations of that past in the neocolonial form. Still postcolonial Indian Muslim societies are promoting and propagating English knowledge at every stage of educational institutions, and thus creating a culturally hybrid/syncretic nation which can neither accept Englishness entirely nor reject its own cultural inheritance and realities totally. Whereas other postcolonial nations can approve, accept and accelerate the mixed-up jumbled cultural syncretism gradually losing or conforming their native cultural signifiers with the Western culture, Muslims cannot because the ideology and approach to life of Islam are straightly opposite to the English knowledge, emanated from the Judeo-Christian and GrecoLatin cultural heritage. Keeping in view the aforementioned ideas, the paper argues that this is high time to point out this epistemological crisis from historical set up and to read English literature from the "Other" point of view. Therefore, it proposes some ways to re-read the English canonical compositions and puts forward as specimen the rereading/teaching method of ENG: 2420, titled "English Poetry: 17th $\& 18$ th Centuries" from the undergraduate syllabus of IIUC.

\section{Occasion for thought:}

In an international conference, arranged by Bangladesh Institute of Islamic Thought (BIIT), on the Islamization of knowledge held in October 2008, I was first triggered by the idea of reading English Literature as a Muslim. The usual answer to the question- How can we Islamize English literature, a knowledge-bank totally different from that of Islam?-which I asked in that conference, was to develop the branch of Comparative literature. But I was not satisfied, though as a student I had often tried to read English history or philosophy comparatively. Since then as a teacher of English Language and Literature I have been finding ways to re-read/teach it from another perspective, from the "Other" perspective - a code, encoded by Edward W. Said, to identify the Non- Europeans. I was thinking about it considering three matters: firstly, the historical trans/formation of our identity in Indian Subcontinent -once the inhabitants of pre- and post- British ruled Indian Subcontinent; then, of East Pakistan and finally, of Bangladesh. Secondly, as the postcolonial beings we share 
and at the same time as Muslims we dispel our experiences with the entire postcolonial world; Finally, our understanding of the English life and culture is unlike that of the settler Muslims living in the English societies - either European or American or that of the Muslims in the Middle-eastern countries.

\section{Flow of discussion:}

As such this paper comes up with three parts: firstly, it dismantles the history and purpose of placing English literature in the colonial India and focuses on the drastic up and down of the Muslims' fortune in India and the subsequent consequences of it on their identity formation; in the second part, it will propose some views of re-reading/teaching English literature from perspective of the "Other"; lastly, it offers a pragmatic approach to re-read/teach a particular course in IIUC. Thus I would indicate how, being fragmented to the vein, intensely we are suffering the pain of epistemological predicament.

\section{Part I}

English literary studies in India are the by-product of the British Imperialism. As "education effects, in Gramsci's terms, 'domination by consent," (Ashcroft, Bill et al 425) introduction of English literature was a safe route to rule the Indians culturally along with politically. Literature, peopled by "the best and wisest Englishmen," (qut. Viswanathan 437) influenced the internal mind of the Indians so profoundly that no missionary or political process could do so. Because literature is the meeting place of personalities "of a more personal kind" ( qut. Viswanathan 437) that makes the readers verify, justify and rectify the situations and events from an inward comprehensiveness. It is never easy to upset since literary world virtually removes the readers from the material world, the world "of ongoing colonialist activity - of commercial operations, military expansion, administration of territories," and forces them to forget the identity of the Englishmen "as a subjugator and alien ruler." Literature with its "humanistic functions" shapes character and develops an aesthetic and ethical thought (Viswanathan 437,431). It makes the natives "willingly submit from a conviction that we[the British] are more wise, more just, more humane, and more anxious to improve their condition than any other rulers they could have"(qut. Viswanathan 436). With this view, Thomas Babington Macaulay, "the architect of English education in India" in his 1835 "Minute on Indian Education" informs the government about its responsibility to create a class of interpreters who would be glorified by being taught in 
English the Englishness and happy to serve the interest of the Imperial power:

We have to educate a people who cannot be at present be educated by means of their mother-tongue. [...]. The claims of our language it is hardly necessary to recapitulate. It stands pre-eminent even among the languages of the west [...] It may safely be said, that the literature now extant in that language is of far greater value than all the literature [...] We must at present do our best to form a class who may be interpreters between us and the millions whom we govern; a class of persons, Indian in blood and colour, but English in taste, in opinions, in morals, and in intellect. (428-430)

Thus "imperial education systems interpellated a colonialist subjectivity not just through syllabus content, or the establishment of libraries within which the colonial could absorb the lesson of the master', but through internalizing the English text, and reproducing it before audiences of fellow colonials" (Ashcroft, Bill et al 426). This can be phrased, as Gandhi, the scheme to have "English rule without the Englishman' (Chakrabarty 230).

The history of the initiation of the English literary studies in India is interesting to read. The most effective account comes from Gauri Viswanathan compiled in his "The Beginnings of English Literary Studies in British India". After the battle of Plassey the profitable trade of the English turned to a horrific political dominance. At that time still both Hindus and Muslims could maintain their own cultural practices without any interference of the English culture. Gradually the Orientalists, directed by the East India Company, mastered the indigenous languages through the linguistic and philological study of the East. Through this linguistic knowledge they became familiar with the Indian literature, customs and religion and that was the beginning of the effective Imperial rule (O'Reilly 16-17). Effective rule meant control by full consent - internally and externally, and nineteenth century saw it in its full bloom. Gauri Viswanathan relates: "English literature made its inroads in India, albeit gradually and imperceptibly, with a crucial event in Indian educational history: the passing of the Charter Act of 1813" (431). It focused on the role of Britain in the field of education in India: one was an expression of responsibility towards the education of the natives and the other was to permit the missionary activities here under the supervision of the authority. But when the missionaries entered India after 1813 the English parliament 
in order to preserve 'religious neutrality' strictly controlled the widespread preaching and teaching of Christianity here. The government only encouraged Oriental studies as an effectual way to secure control over the Indians. But that did not prove enough for 'moral and intellectual improvement' of the natives which was the target of it. To achieve that end, after the passing of the English Education Act in 1835, English literature, along with the Oriental studies, was introduced in the educational institutions.

Nevertheless, not only the missionaries but also all the English world could not accept the reading/ teaching of their literature from secular perspective. They considered it a fruitless effort pinpointing that "texts read as a form of secular knowledge were 'a sea in which the voyager has to expect a shipwreck" (433). Such texts could not have any moral impact on the reader. Furthermore, it was a strong belief that to study English literary texts demanded "a high degree of mental and moral cultivation" (433) that could come only from the amalgamation of Christianity with the textual basis and interpretations. The authority compared the colonial subjects with the lower classes people of England who must have been educated in religion only. They felt that both Hindus and Muslims were living in darkness, in "ignorance and degradation" (434) from which their respective religions could not rescue them. English literary study then was proposed as a remedy where secularism and religion could be fused harmoniously without being provocative to the natives' feeling for their own religion. Surprisingly enough, it was the period when in the British Curricula English Literature as a discipline had "no firm place" (434). It was introduced in London and Oxford universities after the induction of a 1000 paper on English literature in the Indian Civil Service examination.

The imperial authority started to analyze English texts surfacing Christian elements subsequently. Missionaries expressed their high estimation of English literature in the following way: [...] as the 'grand repository of the book of God' England had produced a literature that was immediately marked off from all non-European literatures, being 'animated, vivified, hallowed, and baptized' by a religion to which Western man owed his material and moral progress" (qut.435).They compared other literatures with the Cave of Plato where the inhabitants are chained and devoid of the true light of knowledge. Macaulay told "[...] a single shelf of a good European library was worth the whole native literature of India and Arabia" (O'Reilly 17). Accordingly, in the Indian curriculum those 
texts are incorporated which "upheld the Christian faith" (435).It is reported in this way:

"The process of curricular selection was marked by weighty pronouncements of the 'sound Protestant Bible Principles' in Shakespeare, the strain of serious piety in Addison's Spectator papers, the 'scriptural morality' of Bacon and Locke, the 'devout sentiment' of Abercrombie, the 'noble Christian sentiments' in Adam Smith's Moral Sentiments” (qut.435).

Bill Ashcroft et el in their The Empire writes Back: Theory and practice in Postcolonial Literature also provide an insightful analysis of the colonial education policy. They affirm that Victorian Britain through colonial education system reinforced centre/periphery dichotomy hugely in its disparate empire. It set for the in-school 'readers' a normative core of British literature, landscape and history through Browning's thoughts in exile, Wordsworth's daffodils, and Sir Philip Sydney's chivalry, and through Stanley's explorations or Newbolt's desperate cricketers presented stories of colonial adventure which asserted British values against a hostile physical or human environment (18). Thus English course became a part of the Indian curricula that "enjoyed a different status" and was turned out to be a subject to be "attended by a different set of students", especially students of high caliber and talent (433).

This emphasis on studying English Literature "rather than studying issues such as grammar or diction" (McLeod 141) in Indian curricula became synonymous to study and acquisition of morality. John McLeod tells that during colonial regime English literary texts were interpreted in moral terms as the conveyers of universal and timeless truths, endowed with Christian values. To study those texts meant study of models of morality lied at their heart. Thus the moral behaviour and English behaviour became one and the same and "the English texts became a surrogate Englishman in his highest and most perfect state." In this way, while reading this body of texts Indian students met a code of values -simultaneously Christian and universal. In this context we can remember Jamaica Kincaid. He shared his experience as a student of reading English 'classics' telling that they used to study the Brontes, Hardy, Shakespeare, Milton, Keats sitting under a tree in Antigua with the understanding that western nations 
could produce 'the very best in art and learning', the value of which could survive in faraway places from the land of production (140-142).

English literature and culture thus claimed its superiority over all the other cultures in the colonial period: "it represents the colonized to themselves as inherently inferior beings- 'wild', 'barbarous', "uncivilised" (Ashcroft, Bill et al 426). For this there was an unbridgeable gap between the giver and receiver of the knowledge. The receivers- Africans, Chinese, Indians, Muslims and women- are presented in most of the authoritative English texts as passive, dull, lusty, inferior and wild. Literary studies inject such assumptions so minutely in the plot, action and development of the story that the native readers nourished and are still nourishing "the greatest desire to raise themselves to the level of moral and intellectual skills of their masters; their most driving ambition, to acquire the intellectual skills that confirmed their rulers as lords of the earth" (Viswanathan, Gauri 436). Ziauddin Sardar also pointing to the 'suffocating past' and 'fragmented present' of Asia, tells that colonial powers consciously and systematically suppressed the Asian culture and replaced it with their own cultural characteristics with a dominant image, that is, the image of western culture as a standard for civilization. The colonized societies hence started to think that the only way to dignity and identity was to be like the west (Islam, Postmodernism and Other Futures 264-265).

After this colonial domination the postcolonial era started with seemingly political independence, not with the hegemonic freedom. Elleke Boehmer in his Colonial \& Postcolonial Literature opines "making a postcolonial world meant learning how to live in and represent that world in a profoundly different way. But that was far from easy" (178).To be independent meant "purna swaraj" (complete independence), as Gandhi, with "a cultural identity" and to search for roots, origins, myths and history for having an authentic selfdefinition, self-making and nation-building by insulting and vomiting, as Fanon, the white man's values (174-177). Raymond F. Betts expresses the same thing thus: "[...] decolonization required much more: a fundamental change of outlook and attitude, of heart and mind. [...] a 'bush clearing' (88).

Yet the west left, but left two cultural legacies in Asia that have given birth a melancholic instability and fragmentation in individual, communal, national and regional level. The first colonial legacy is the 
eighteenth-century European concept of nation-state and the other is the rule of the nationalist bourgeoisie that 'internalized the image of the west as the yardstick of cultural behaviour'. The crisis of the formation of nation-states was that they were created with fabricated boundaries combining a diverse array of communities and ethnic cultures. Yet as nations were artificial and not natural entity, it scattered the same ethnic and religious communities into a number of different states. Therefore, both the physical and mental geography of the nations became an unending battlefield. In the one hand, the various nations claimed their right over each other's territories and on the other hand, each ethnic group wanted to achieve their cultural autonomy through the established national identity. Nations did not prove a harmonious balance of many into one (McLeod 72) with the aim to prosperity.

On the other hand, after independence when the nationalist elite got the state power, it 'with its occidental worldview and images,' followed a westernized pattern of cultural and political 'progress' and 'development'. The word development became synonymous to modernization and the belief in the scientific power and application of the technology in all levels. Through this development the ruling class tried to transform the whole societies including their culture and belief systems. To the ruling elite the west was the peak of civilization and the local cultures were at the bottom of this hierarchy. At any cost it preserved this image because the destruction of it meant the damage of self-image and self-satisfaction. In the midst of this the group that reserved the traditional cultures and beliefs felt out of water and there arose a constant tension between the elite and the common citizens with their traditional outlook and images (Sardar 265-267). Hegemonic dominance ensued and consolidated thus and like Frankenstein neo-colonialism 'played havoc with the defining parameters of the identities' through 'the imposition of the western framework of culture' (Sardar 265) here.

We cannot deny that the attempt of making and remaking identity was very much present in the post-independence era. In order to repair the damaged self of the nation, there came an overwhelming uprising and popularity of the revival of legends of "historical atonement," that is, "the account of a community's coming-into-being" (Boehmer 188) and the rich and fruitful existence of the past, tales of heroic deeds, bold story of the nationalist leaders and martyrs, portrayal of the mythic figures, description of the native nature, landscapes, love 
stories, loss and sorrow. But that romantic revival became fruitless when the neo-colonial aggression directly and indirectly, consciously or unconsciously affected it making the country a cauldron of corruption, division, injustice and chaos.

Under these circumstances, education system remained in the previous place with the permanent traces of colonialism. There came a little or no change in the epistemological schema of the pre-established curricula:

"Political independence changed relatively little educationally in most developing countries. Few countries, despite the militancy of nationalist movements or deep feelings of enmity toward the former colonial powers, made sharp breaks with the educational past. In most cases, for example, India, Pakistan, Burma, and Singapore, the educational system expanded quantitatively, but did not alter much in terms of curriculum, orientation, or administration"

\section{(G. Altbach 454).}

Both traditional and modernized educational policies prove inadequate and partial and are continuously at war against each other. Moreover, in the university syllabus anglocentric assumptions gets stronghold. It imparts that 'standards' can only be formed by studying the great tradition of English literature, from Chaucer on [...] Metropolitan literature is universal, [...]. The consequence of the anglocentric assumption is that English literature must remain as the 'core' of a student's courses" (Docker 443-444). Ngugi Wa Thiong'o could not support this centrality of the English department in Africa when the Acting Head of the English department presented a paper in a Board meeting on the 22th September 1968 declaring it as "the central root of our consciousness and cultural heritage" (On the Abolition of the English Department 439). Instead he proposes the abolition of the English Department and placement of the Department of African languages and Literature there as the centre.

Hence the native students, readers and writers are exposed to the modern poets and writers from the West included in the university syllabuses and become syncretic and culturally hybrid. Hybridity is a technical term that means 'a cross between two different species' (qut.McLeod 173), by grafting to form a third one. In postcolonialism 
it refers to 'the creation of new transcultural forms within the contact zone produced by colonization'. Hybridization can take many formsLinguistic, cultural, political, and racial (Ashcroft et el 118). Benedict Anderson finds the idea of 'mental miscegenation' in colonial education policy that aimed to create Europeanised natives Macaulay dreamt of in his Minute. The underlying assumption of this syncretism is the Indians will mimic, but would not be able to reproduce English values exactly and thus there would remain a gap that would ensure their subjection (Loomba/Ania 173). So with the mark of colonial assumptions on the forehead, the newly-independent nations of Indian Subcontinent created culturally hybrid peoples. They became ambivalent in their creed and manner "with the concepts of the anarchic postcolony, the transgressive trans-local, and the infinitely co-optable multi-cultural" (Boehmer, Elleke 247) and produced and are producing syncretism - "the blending of their different cultural influences, an upfront and active syncretism"-splitting themselves between their traditional identity and a modernized environment that labels the former as intrinsically inferior (Sardar 267-268).

\section{The Case of the Indian Muslims:}

Against this general background I want probe into the matters of Indian Muslims separately that will justify my attempt to propose new ways to re-read/teach English Literature. The fortune of the Indian Muslims underwent drastic changes from the British colonial to Bangladesh period. Here, as a result of the wide-range invasion of Arabian and Persian Muslims - for trade or business - Islam got its strong foothold as one of the most populous religions. For more than nine centuries, Muslims ruled this region with glory and splendor. The first comers of the British honoured its glorious power, elaborate rituals, courtly manner, hospitality and magnanimity with awe. When in 1608 the first ships of the East India Company anchored in India, the Mughal Emperor Jahangir welcomed them as guests and accepted them as traders with magnanimity. As this was 'a land of exile', unfamiliar and far away from their home, they adapted themselves to the laws and customs of Indian society for the next two centuries. The British felt comfort in their dealings more with Muslims than Hindus because of their shared religious background and higher social status. But this harmony did not last longer. The relationship between the West and Islam was 'protracted' and 'tumultuous' before the former became a colonial power. It used to view Islamic world with suspicion as political and economic rival since the Middle Ages when Islamic civilization tried to expand its light into the Dark Europe. The bloody Crusades were the 
beginning of the animosity and policy of 'mutual defensiveness' of these two cultures. So, while the British was entering India for trade or missionaries, Islam was 'hardly strange and incomprehensible' to them. Moreover, it was the only religion that had strength and valour to have existence outside the national boundary. Hence, so far the British felt the power of Muslim rulers, they remained tame and gentle. But the Industrial revolution, technological advancement and later on, the opening of Suez Canal in 1896 changed their attitude towards their land of exile. Their scientific advancement and faster communication with home through Suez Canal removed the need to adapt to the Indian cultural aspects. They emerged as 'a real military and political threat to the local princes' who in turn fought continuously till 1857 Mutiny. But by this time the face of India had totally been altered. All the high posts of government and legislation were replaced by the English leaving only 'the Indian servant, the clerk, the merchant and the banker as representatives of India and Indian cultures'. Nevertheless, despite the failure of this Mutiny, Muslims with the hatred to the Dar-ul-Harb, the land of the unfaithful, continued their violent attack on and fighting against the British under the leadership of Shah Waliullah, Shah Abdul Aziz or Titu Mir etc at intervals.

Soon the British felt the necessity of relaxation and 'enticement' to take control over the discontent and militant Muslim population. They offered them the boon of English education and then promised the establishment of Dhaka University in East Bengal as it was a Muslim majority area. Gradually the colonial government recognized 'the Muslims as a separate nation entitled to a homeland of their own'. Accordingly, in 1906 came the Partition of Bengal giving the Muslims a land of their own. But when it was annulled on the pretext of violent opposition of Bengali Hindus, Muslims became bitterly resentful. They realized the need for a 'more concentrated effort for their rights' and kept themselves aloof from Swadeshi Movement of Hindus. They founded a separate political forum named All India Muslim League to exert their rights from the colonial master. Thus, when demand for separate home for two nations was accumulating, the parting British imperial power in 1947 divided India in two uneven halves - India and Pakistan. Nevertheless the unity of two disparate land and culture under 'the banner of Muslim nationhood' failed to bring what had been hoped for. Within five years the blood of East Pakistani Muslims was dropped on language issue and then injustice, economic oppression and inhumane genocide of the Military Junta gave the birth pangs of a regional independent nation Bangladesh (Durdana, Benazir 3-38). 
This turbulent period of the fate of Indian Muslims had a significant impact on their identity. Actually, India was a place of diversity and difference with cultural pluralities. Here 'language-based regional subcultures' were as prominent as many sectors in Muslims and Hindus. Moreover, Islam here became 'stamped with certain distinct characteristics of indigenous culture of India' and following the basic Islamic teachings, 'Bengali Muslims shared many social practices with Bengali Hindus. This produced a 'hybrid self-identity' that was 'perpetually confronted with a crisis of identity involving regionalism, state nationalism and pan-Islamic internationalism.' For this reason, the totally culturally disparate two wings of Pakistan, united only on the basis of same religion, could not cling to each other, and for 'another national identity' there arose the necessity of the Liberation War in 1971. Nevertheless, this did not end the identity crisis. Still, after forty years of independence, 'ethnicity and religious sentiment continue to be uneasy consorts in Bangladesh's concept of nationhood' (Durdana, Benazir 49-53).

Recently, the identity of Bangladeshi is a warlike field. In one hand, the Hindu culture as a form of ancient heritage of 'Hindustan' before the conversion of this region to Islam and demonization of Islam as a dangerous influence are trying to be prevalent and on the other hand, the continuous assault is leashing on Muslim self due to the random incorporation and assimilation of English literary and linguistic practices in every stage of educational institutions. So, Muslims are always in perpetual confusion about Islam, its relationship with the colonial masters or the war of Independence or the neo-colonial West and considering it totally obsolete in the modern era ends up in neither this nor that but something culturally hybrid, yet unlike the hybrid in the colonial era. Under the roller of triple pressures of Hindu rituals, Westernization and misrepresentation of Islam they are gradually losing their cultural signifiers related to Islam and thus virtually segregating their practical relationship with it.

A Muslim can be hybrid, but not at the expense of the basic faith and essential practices. Whereas other cultures and religions can open up a reconciliatory and compromising mixed up route, randomly infusing English culture and value with its cultural signifiers, Muslims cannot but mock it in so doing, because Muslim cultural symbols and signifiers come always in conflict with the Englishness. So at present to be hybrid means for Muslims to be a modern man shedding their Muslim identity. They do not realize that hybridity is the state of being that acknowledges 
the existence of two antagonistic cultures in self as a part of each other. It does not a condition for deculturation of Islam or acculturation of the Englishness, but transculturation of both with careful selection of values and practices from each. For this reason, they are in a painful 'inbetweenness' losing in-place identity as Muslims.

\section{Part II}

In today's in-betweenness of Muslims, the call for in-place identity is a difficult path to follow. I am placing here only one way to do so in the academic level, specifically in the English Departments, that is, to reread/teach English literature from a hybrid perspective, integrating Islamic truths with other cultural assumptions that solely are reining this field. This integration will give the gradual-lessening Islamic ideas and ideals to come in view of Muslim students of English Literature. As the Imperial power could not remain religion-neutral, nor can the Muslim societies. Meenakshi Mukharjee puts an interesting concept about this re-reading of English literature in postcolonial condition: it [postcolonialism] makes us interrogate many aspects of the study of literature that we were made to take for granted, enabling us...to reinterpret some of the old canonical texts from Europe from the perspective of our specific historical and geographical location'(qut. McLeod 138).

About the methods of this re-reading postcolonial scholars like Edward Said or Chinua Achebe have some proposals. As re-reading will be resistance to the assumptions of colonial discourses, 'interrogation' about the literary texts is one of them. Interrogation can take many forms -it can be 'the questioning of the value specific literary texts' as Achebe did with Joseph Conrad's Heart of Darkness or putting 'the literary classics to new uses for which they were scarcely intended' as George Lamming and Aime Cesaire did with Shakespeare's The Tempest. Edward w. Said, on the other hand, puts forward a style of contrapuntal reading-one which remains simultaneously aware both of metropolitan history that is narrated and of those other histories against (and together with which) the dominating discourse acts (McLeod 142-147). Besides, appropriation of Shakespeare / Joseph Conrad / Kipling in the anti-colonial discourse inside and outside the educational systems is also a favourite formula-to upset the coded meaning of the writings. David Johnson did not support this saying, "to appropriate Shakespeare will only retard the move towards a fresh, more meaningful curriculum." Decolonization demands the rereading/teaching of the texts of both Western and non-Western writers 
"to revise our view of European culture" and to create knowledge with our cultural belongings (Loomba, Ania 93-94).

Keeping in consideration the re-reading methods of these scholars, I will propose here some ways to re-read/teach English literature from hybrid viewpoint integrating Islamic one with them. They are the following: re-reading/teaching a) based on difference; b) based on the representational politics; c) based on a historical approach; d) with focus on identical human elements.

The first way will focus on differences invoked in the literary textsgeographical, social, cultural and linguistic differences. English literary texts place a stony area to trip for the outsiders of Europe. Though they start with the prepared mind to meet something universal, the books remain hazy, unfamiliar and inaccessible. Some teachers and students of this field express their experiences of reading/teaching in different places outside English arena. Charles Larson in his "Heroic Ethnocentrism: The Idea of Universality in Literature" relates that in Nigeria he was teaching English Literature in 1962. The students were reading Thomas Hardy's Far from the Madding Crowd. They asked a number of questions which were unimaginable to be asked by such adult students, such as, "Excuse me, sir, what does it mean "to kiss"?" or "What is a flush toilet" or asked about the page after page long description of the unfamiliar landscape in Hardy's novel (62-67). Ngugi Wa Thiong'o describes the lack of correspondence between colonial education and the students. To his son "the daffodils of Wordsworth's poems are 'just little fishes," or Alofa, a schoolgirl, considers these mythic flowers dancers living in the sky, or Lucy, a Caribbean in the USA, cannot realize the beauty of the daffodils. Naipaul also expresses that as a Trinidadian man when he heard the line 'lowing herd winding o'er the lea' from Gray's Elegy, he could visualize only the cows on the condensed-milk tins, because their island had no such cows (Boehmer, Elleke 180). When I teach English history in the classroom, I find students puzzled over the repetition of names of English Kings and queens just only with changes in their numbers as I, II, or V. Therefore in the classroom a teacher can focus on these differences related to socio cultural practices and geographical location in the very beginning of and along with the reading of the texts, and during reading $\mathrm{s} / \mathrm{he}$ can ask questions on what type of disassociated images are gathering in their minds. In examination he can set at least $10 \%$ questions on this explicit use of differential symbols and signifiers. This process I think will be able to help the natives to overcome sense of dislocation and grasping 
the differences and diversities, they will be able to relocate them in their own space.

English literature is abounding in representations of the "Other" in accordance with the nature/culture, primitive/developed, we/the Other, rational/irrational etc. binary oppositions. Elleke Boehmer tells that the processes of othering are fundamental in colonization and in literature representation of the inhabitants of the colonized lands is stereotypical as well as metaphorical .This representation defined the self of the colonized "as lesser: less human, less civilized, as child or savage, wild man, animal, or headless mass" (75-76). Moreover, during eighteenth century the scientific explanations of racial hierarchy started marking the white as superior and the others-black; brown etc. - as inferior and savage. In re-reading/teaching literary texts-like Heart of Darkness, A Passage to India, Othello, Robison Crusoe, The Tempest, Kim, etc-we have to dismantle and resist the sketches of Muslims, Hindooes, Africans, Arabians minutely. It will establish a strong self with a "sense of difference which is not pure "otherness" (Loomba, Ania 182) in regard to own cultural assumptions.

The next approach is the historical approach-to teach English history with reference to its colonial days and to read history as a cotext in reading a literary text. Ngugi Wa Thiong'o expressed his surprise at teaching European 'Renaissance,' 'Reformation,' or 'Enlightenment' isolated in the postcolonial societies. The Indians have a long history of origination, development, and resistance in the pre, during and post British era. The Muslims have a glorious history of preaching, conversion, and affluent Empires here. We have to take into account that history of informal schooling of the Indian Muslims, and try to relate it with the British educational assumptions we find in "Idea of a University" or Areopagitica or Bacon's essays etc. This will give us scope to have a glimpse into our belongings and to enumerate and assess the historical mistakes that have led us to these anarchic concepts of ourselves.

I named the final mode the study based on identical human elements. This does not mean similarity between the natives and the West, if any. It is sameness in difference, similarity rooted in the rudimentary human feelings, passions and emotions irrespective of the time and space. This strategy will raise questions like that: What would you do if you were Hamlet whose father was unjustly murdered and then his mother got married again? Or what would you feel if you were 
Heathcliff treated like 'a thing' in a fostered house? Or what does Donne implicate when he utters "Nowhere /lives a woman, true and fair." Or does a mother having five young daughters think and behave in the manner Mrs. Bennet does? Such questions will bring literary studies near to life, disseminate the human and humane approach to life, and focus on the internal contradictions, incongruities, and deficiencies - natural or artificial - of society and state apparatus. This will pave the way to go beyond narrow, blind and parochial chauvinistic approach to literature.

\section{Part III}

In this section I will place a proposal to apply the above-mentioned strategies of rereading/teaching English literary texts in the universities having English departments in postcolonial Muslim societies. It is a specimen about what changes we can bring in our dealing with English canonical texts. My attempt is only to provide a 'superstructure' that can remake and reset ideas in the minds of the Muslim students of English, not any technical methods, as without a specific purpose techniques are useless. The chosen course is ENG: 2420, titled "English Poetry: 17th \&18th Centuries" from the undergraduate syllabus of IIUC. It includes four poets:

1. The Metaphysical Poets:

a) John Donne: selections from Song and Sonnets

b) Andrew Marvell: "To His Coy Mistress" "The definition of Love," "The Dialogue between Body and Soul"\& "Bermudas"

2. John Milton: Paradise Lost, Book I\&II;

3. Alexander Pope: The Rape of the Lock.

- The superstucture/ ideological basis of re-reading/teaching can be the following:

a) Outline for Paradise Lost:

1. The legend of the fall of man: a. The truth of the creation and fall of man in Islam;

b. The myth of the creation and fall of man in Christianity; c. The idea of the evolution in Indian Hindoo mythology \& Darwin's theory of evolution; .d. The myth of that from Greco-Roman world. 
2. Cosmology: Hell, Heaven \& Earth-a. Islamic cosmology; b. The Greco-Roman ideas; c. Milton's epic employed which tradition? Discrepancies and conceptions.

3. Character analysis: a. Satan-from Islamic view; discussion on interpretations of him in Renaissance as a hero, and formation of counter-discourse.

4. Epic Simile: a. Mythic, Natural, Biblical \& Imperial; b. natural scenarios invested in epic; c. remote geographical and cultural sites

5. Sketch of Hell-Islamic, Biblical and Miltonic: Similarities and differences

b) Outline for The Rape of the lock: 1. The Role of women in the society-Idea of Hellenic period, Christian era and Islamic philosophy; 2. The legacy of Empire: trade, luxury and moral values; 3. Man-woman \& woman-woman relationship in Pope's World and keys for a harmonious relationship; 4 . Theme of beauty, value and violation in the context of this mock-epic.

c) Outline for the metaphysical poems: 1 . The view towards human life: Hedonism and Islamic view; 2. The place of love in human life: compare and contrast spiritual \& physical bond between manwoman; 3.origin \& history of scientific development in the world: body of scientific knowledge in the seventeenth century used by Donne \& Marvell. 4. Religion and the understanding of the metaphysical poets: compare and contrast with Islamic idea.5.Representation of women in the poems and agreement with or resistance of those ideas.

This ideological basis will work to restructure and renovate the mind of the students illuminating their internal territory. They thus will be able to think from the very near of their own cultural heritage and out of the trendy mental slavery offered by the neocolonial ways of thought.

\section{Conclusion:}

The above discussion - analysis of the placement of English literature in India and the turbulent up and down of fortunes of Muslim and their identity crisis-along with the proposals and pragmatic approach, would be able to construct a counter-discourse on face of the counterwave pulling towards an anarchic identity of Muslims in postcolonial societies. Muslim students of English literature would find food for their intellect from this and would attempt to remake an in-place cultural hybridity without epistemological predicament. And with this 
formation of cultural identity, the Muslims, one of many 'Others,' will speak back.

\section{Works Cited}

Altbach, Philip G. "Education and Neocolonialism.” Bill Ashcroft et al 452-456.

Ashcroft, Bill et al.Ed. The Post-Colonial Studies Reader. London and New York: Routledge, 2003.

Ashcroft, Bill et al. The Empire Writes Back: Theory and practice in Post-colonial Literatures. London: Routledge, 2002.

Ashcroft, Bill et al. Key Concepts in Post-colonial Studies. London: Routledge,2004.

Benazir, Durdana. Muslim India in Anglo-Indian Fiction. Dhaka: writers.ink,2008.

Boehmer, Elleke. Colonial \& Postcolonial Literature .New York: Oxford University Press, 2006.

Chakrabarty, Dipesh.Postcoloniality and the Artifice of History: Who speaks for 'Indian' Pasts? Padmini Mongia 223-247.

Docker, John. "The Neocolonial Assumption in University Teaching of English."Bill Ashcroft et al 443-446.

Inayatullah, Sohail and Gail Boxwell. Eds. Islam, Postmodernism and Other Futures: A Ziauddin Sardar Reader.London: Pluto Press,2003.

"Introduction." Education. Bill Ashcroft et al 425-427.

Larson, Charles. "Heroic Ethnocentrism: The Idea of Universality in Literature.” Bill Ashcroft et al 61-65.

Loomba, Ania.Colonialism/Postcolonialism.London:Routledge,2001.

Macaulay, Thomas. "Minute on Indian Education.” Bill Ashcroft et al 428-430.

McLeod, John. Beginning Postcolonialism. Manchester: Manchester University Press, 2007.

Mongia, Padmini. Ed. Contemporary Postcolonial Theory: A Reader. New Delhi: Oxford University Press, 1997.

O'Reilly, Christopher. Post-Colonial Literature. Cambridge: Cambridge University Press. 2001.

Thiong'o, Ngugi Wa."On The Abolition of the English Department.” Bill Ashcroft et al 438-442.

Viswanathan, Gauri. "The Beginnings of English Literary Studies in British India." Bill Ashcroft et al 431-437. 